Syntax Literate : Jurnal Ilmiah Indonesia p-ISSN: 2541-0849 e-ISSN : 2548-1398

Vol. 5 No. 3 Maret 2020

\title{
HUBUNGAN PENGUASAAN SINTAKSIS DAN PENALARAAN DENGAN KEMAMPUAN MENULIS PARAGRAF EKSPOSISI (PENELITIAN KORELASI DI STKIP KUSUMA NEGARA JAKARTA)
}

\section{Santoso}

Program Pascasarjana Universitas Negeri Jakarta (UNJ)

Email: sanbk333@gmail.com

\section{Abstract}

This study aims to determine whether or not there is a relationship between syntax mastery with the ability to write an exposition paragraph, (2) the relationship between reasoning and the ability to write an exposition paragraph, and (3) the relationship between syntax mastery and reasoning with the ability to write an exposition paragraph. This type of research is correlational research. This research was conducted at STIKP Kusuma Negara Jakarta. The population is the $3 r d$ semester students of STKIP Kusuma Negara Jakarta with a sample of 33 people taken randomly. The instruments used to collect data are written tests and multiple choice. Data were collected by conducting competency tests on the ability to write paragraph exposition, syntactic mastery comprehension tests, comprehension tests on reasoning. After that the data is analyzed statistically. The data analysis technique used is statistical regression and correlation techniques. The results showed that: 1) there was a positive correlation between syntactic mastery with the ability to write an exposition paragraph, 2) there was a positive correlation between reasoning with the ability to write an exposition paragraph and, 3) there was a positive correlation between syntactic mastery and reasoning together with writing ability paragraph exposition.

Keywords: syntactic mastery, reasoning, writing exposition paragraphs.

\section{Abstrak}

Penelitian ini bertujuan untuk mengetahui ada tidaknya (1) hubungan antara penguasaan sintaksis dengan kemampuan menulis paragraph eksposisi, (2) hubungan penalaran dan kemampuan menulis paragraph eksposisi, dan (3) hubungan antara penguasaan sintaksis dan penalaran dengan kemampuan menulis paragraph eksposisi. Jenis penelitian ini adalah penelitian korelasional. Penelitian ini dilakukan di STIKP Kusuma Negara Jakarta. Populasi adalah mahasiswa semester 3 STKIP Kusuma Negara Jakarta dengan sampel 33 orang diambil secara random. Instrument yang digunakan untuk mengumpulkan data adalah tes tertulis dan pilihan ganda. Data dikumpulkan dengan mengadakan tes kompetensi pada kemampuan menulis paragraph eksposisi, tes komprehensi penguasaan sintaksis, tes komprehensi pada penalaran. Setelah itu data dianalisis secara statistic. Teknik analisis data yang digunakan adalah teknik statistic regresi dan korelasi. Hasil penelitian menunjukkan bahwa: 1) ada korelasi positif antara penguasaan sintaksis dengan kemampuan menulis paragraph eksposisi, 2) ada korelasi positif antara 
penalaran dengan kemampuan menulis paragraph eksposisi dan, 3) ada korelasi positif antara penguasaan sintaksis dan penalaran secara bersama-sama terhadap kemampuan menulis paragraph eksposisi.

Kata kunci: penguasaan sintaksis, penalaran, menulis paragraph eksposisi.

\section{Pendahuluan}

Menulis merupakan salah satu keterampilan yang harus dikuasai oleh mahasiswa. Keterampilan menulis memiliki dampak yang positif bagi perkembangan dan kemajuan mahasiswa itu sendiri. Keterampilan menulis merupakan ekspresi dalam bentuk tulisan, baik berupa ide, gagasan, pendapat maupun perasaan dan pikiran (Muflikh, 2016). Di sisi lain, kemampuan menulis tidak hanya menjadikan seseorang menjadi cerdas dan produktif, tetapi juga membuat mahasiswa mampu berfikir kritis, kreatif, efektif dan efisien dalam menyikapi dan memahami suatu masalah. Selain itu pentingnya kemampuan menulis bagi mahasiswa di sebabkan oleh faktor tugas yang diberikan dosen baik berupa makalah, artikel penelitian, ataupun skripsi yang dalam hal ini sangat dibutuhkan dalam hal keterampilan menulis. Keterampilan menulis juga merupakan sub kompetensi pedagogik yang harus dimiliki mahasiswa sebagai calon guru, karena seorang guru akan mengajarkan bagaimana menulis sebuah teks secara benar kepada siswa-siswanya di sekolah.

Mahasiswa yang memiliki kemampuan menulis dengan baik dan benar mampu menyampaikan ide dan gagasannya melaui pemilihan kosa kata yang tepat, bahasa yang teratur, terarah, dan sistematis sehingga orang lain akan dengan mudah menangkap pikiran yang disalurkan melalui tulisannya itu. (Radford, 2004) menyebutkan bahwa "seseorang yang memiliki pengetahuan tentang tata bahasa akan mampu menuangkan dan menginterpretasikan kata-kata, prasa, dan kalimat di dalam bahasa." Untuk memiliki kemampuan menulis yang baik, seorang mahasiswa dituntut untuk memiliki pemahaman yang luas dalam hal ketata bahasaan baik berupa struktur kalimat dan susunan yang benar, selain itu tulisan juga harus logis serta dengan penalaran yang baik pula. (Ridwan, 2011) mengatakan bahwa menulis merupakan kemampuan yang sangat kompleks. Untuk memilih sebuah tulisan yang diinginkan, penulis harus mengerahkan segenap kemampuannya, meliputi penguatan aspek-aspek kebahasaan, isi tulisan, dan teknik penulisan. Penulis dituntut untuk memiliki berbagai kemampuan sekaligus, berkaitan dengan apa yang akan ditulis dan bagaimana menyampaikannya dalam bahasa tulis yang baik dan benar.

Kaitannya dengan kemampuan mahasiswa dalam menuils paragraf, masih banyak ditemukan berbagai permasalahan. Umumnya permasalahan tersebut berkaitan dengan penguasaan dan pemahaman mahasiswa dalam aspek kebahasaan serta jangkauan berfikir yang rendah hingga menyebabkan mahasiswa sulit menuangkan idenya, sulit menyusun dan merangkai kata dan sulit dalam menggunakan variasi kalimat sehingga tulisan menjadi tidak konsisten. Hal ini disebutkan Chomski dalam (Radford, 2004) sebagai performans error, yaitu adanya missproduction (hasil yang tidak kena sasaran) dan misinterpretation (interpretasi yang tidak tepat sasaran). 
Kemampuan penalaran juga sangat dibutuhkan sebagai suatu kunci kemampuan efektif dalam semua disiplin ilmu pembelajaran, termasuk dalam kegiatan menulis (Rimadani et al., 2017). Penalaran merupakan suatu proses berpikir untuk menarik kesimpulan yang tepat berdasarkan kejadian-kejadian yang ada dan menurut aturan tertentu (Nursalam et al., 2017). Dengan adanya penalaran seseorang mampu menjelaskan suatu konsep dengan baik, mampu membuat suatu argumentasi untuk membantu seseorang mengembangkan pemahaman yang kuat tentang sesuatu (Rimadani et al., 2017).

Penelitian (Agustin, 2015) menunjukkan adanya efek yang signifikan dari penguasaan tata bahasa dan berpikir logis terhadap kemampuan menulis artikel ilmiah. Apabila kemampuan penguasaan tata bahasa dan berpikir logis seseorang baik maka kemampuannya dalam menulis akan baik juga. Temuan lainnya oleh (Siahaan, 2016) menunjukkan adanya korelasi antara kemampuan berpikir logis dan pengetahuan tentang paragraf terhadap menulis esai bahasa Inggris seseorang. Kedua penelitian tersebut menunjukkan pentingnya kemampuan penguasaan tata bahasa dan berpikir logis terhadap kemampuan menulis seseorang.

Permasalahan yang ditemukan oleh peneliti di Program Studi Bahasa Indonesia dan Daerah pada mata kuliah menulis di STKIP Kusumanegara Jakarta. Berdasarkan hasil observasi, analisis dilakukan dengan mengamati hasil tulisan mahasiswa yang cenderung tidak kreatif, copy-paste, dan asal-asalan serta dari nilai-nilai yang diperoleh oleh mahasiswa yang cenderung di bawah rata-rata. Secara umum dosen telah memberikan pengajaran dengan baik, namun dalam pelaksanaannya mahasiswa masih belum memberikan hasil kerja yang memuaskan. Berdasarkan gambaran umum kondisi objektif dari hasil pembelajaran menulis teks atau paragraf tersebut, bahwa hasil pembelajaran yang ditemukan adalah kurangnya kemampuan menulis mahasiswa dalam membuat text atau paragraf.

Melihat kondisi tersebut maka diperlukan adanya sebuah penelitian untuk mencari akar masalah dari kurangnya kemampuan mahasiswa untuk menulis sebuah teks atau paragraf dengan baik. Berdasarkan uraian pada latar belakang di atas, dalam hal ini peneliti termotivasi untuk menulis tentang hubungan antara penguasaan sintaksis dan penalaran dengan kemampuan menulis paragraf eksposisi di STKIP Kusumanegara Jakarta.

\section{Metodologi Penelitian}

Metode penelitian yang digunakan dalam penelitian ini adalah penelitian korelasional. Penelitian ini merupakan penelitian kuantitatif jenis penelitian korelasi. Sampel penelitian ini diambil dengan menggunakan teknik random sampling yaitu sebanyak 33 mahasiswa semester 3 di STKIP Kesuma Negara Jakarta. Adapun variabel bebas (independent) yang digunakan dalam penelitian ini ada dua yaitu penguasaan sintaksis (X1) dan penalaran (X2) sedangkan variabel terikat (dependen) adalah kemampuan menulis paragraf eksposisi (Y1). Tes yang mengukur penguasaan sintaksis dan penalaran diberikan dalam bentuk tes pilihan ganda berjumlah 30 soal yang 
dirancang oleh peneliti disesuaikan dengan kerangka teori dan kebutuhan penelitian, sedangkan tes kemampuan menulis paragraf eksposisi diberikan dalam bentuk mengarang. Sebelum instrumen penelitian digunakan dilakukan uji coba. Selanjutnya peneliti menguji validitas dan reliabilitas instrumen tersebut, serta menguji taraf kesukaran dan daya beda pada instrumen tes. Teknik analisis data yang digunakan pada penelitian ini adalah: (1) uji prasyarat analisis meliputi uji normalitas, linieritas, dan multikolinieritas; (2) analisis statistik deskriptif; dan (3) analisis pengujian hipotesis menggunakan korelasi sederhana, korelasi ganda, uji signifikan, uji regresi sederhana, uji regresi berganda dan koefisien determinasi.

\section{Hasil dan Pembahasan}

\section{A. Hasil}

\section{Uji Normalitas}

Pengujian normalitas dimaksudkan untuk menguji apakah populasi berdistribusi normal atau tidak, sehingga dapat dipakai dalam statistic nonparametik. Dalam penelitian ini uji normalitas dengan menggunakan onesampel Kolmogorov-Smirnov Test yang menghasilkan angka probabilitas atau Asym Sig. (2-tailed) sebesar $0.442>\alpha(0.05)$.

\section{Uji Linearitas}

Berdasarkan hasil perhitungan dari tabel output "Anova" variabel kemampuan menulis paragraf eksposisi (Y) dan penguasaan sintaksis (X1) diperoleh nilai Deviation from Linearity Sig. sebesar 0.637 lebih besar dari 0.05. Selain itu berdasarkan nilai $\mathrm{F}$ diperoleh nilai $\mathrm{F}$ hitung sebesar 0.841 kebih kecil dari $\mathrm{F}$ tabel $\left(\mathrm{F}_{\text {tabel }}=2.33\right)$.

Sedangkan pada output "Anova" variabel kemampuan menulis paragraf eksposisi (Y) dan penalaran $\left(\mathrm{X}_{2}\right)$ diperoleh nilai Deviation from Linearity Sig. sebesar 0.351 lebih besar dari 0.05. Selain itu berdasarkan nilai $F$ diperoleh nilai $\mathrm{F}$ hitung sebesar 1.208 kebih kecil dari $\mathrm{F}$ tabel $\left(\mathrm{F}_{\text {tabel }}=2.33\right)$. Maka dapat disimpulkan bahwa ada hubungan linear secara signifikan antara variabel penguasaan sintaksis $\left(\mathrm{X}_{1}\right)$ dan penalaran $\left(\mathrm{X}_{2}\right)$ dengan variabel kemampuan menulis paragraf eksposisi (Y).

\section{Uji Multikolinearitas}

Berdasarkan hasil perhitungan dari tabel output "coefficients" pada bagian "colinearity statistic" diketahui nilai toleransi untuk variabel penguasaan sintaksis (X1) dan penalaran $\left(\mathrm{X}_{2}\right)$ adalah 0.426 lebih besar dari 0.10. Sementara nilai VIF untuk variabel penguasaan sintaksis (X1) dan penalaran $\left(\mathrm{X}_{2}\right)$ adalah 2.348 kurang dari 10.00. Maka mengacu pada dasar pengambilan keputusan dalam uji multikolinearitas dapat disimpulkan bahwa tidak terjadi gejala multikolinearitas dalam model regresi. Berikut ini adalah tabel dari uji multikolinearitas dengan menggunakan SPSS. 


\section{Uji Heteroskedastisitas}

Berdasarkan hasil perhitungan uji heteroskedastisitas dengan uji glejser, dari tabel output "coefficients" diperoleh nilai signifikansi (Sig.) untuk variabel Penguasaan Sintaksis (X1) adalah 0.921. Sementara, nilai signifikansi (Sig.) untuk variabel Penalaran $\left(\mathrm{X}_{2}\right)$ adalah 0.585 . Karena nilai signifikansi kedua variabel di atas lebih besar dari 0.05 , maka mengacu pada dasar pengambilan keputusan dalam uji glejser dapat disimpulkan bahwa tidak terjadi gejala heteroskedastisitas dalam model regresi.

\section{Analisis Hipotesis}

Analisis hipotesis menggunakan analisis korelasi sederhana, analisis korelasi ganda, uji signifikan, analisis regresi linier, regresi berganda, dan koefisien determinasi. Hasil perhitungan dapat dilihat pada tabel 1 dan tabel 2 berikut.

Tabel 1 Hasil Uji Regresi Variabel $X_{1}$ dan $X_{2}$ Terhadap Variabel $Y$

\begin{tabular}{|c|c|c|c|c|c|}
\hline \multicolumn{6}{|c|}{ Coefficients $^{\mathrm{a}}$} \\
\hline \multirow[b]{2}{*}{ Model } & \multicolumn{2}{|c|}{$\begin{array}{c}\text { Unstandardized } \\
\text { Coefficients }\end{array}$} & $\begin{array}{c}\text { Standardized } \\
\text { Coefficients } \\
\end{array}$ & \multirow[b]{2}{*}{$\mathrm{t}$} & \multirow[b]{2}{*}{ Sig. } \\
\hline & B & $\begin{array}{l}\text { Std. } \\
\text { Error }\end{array}$ & Beta & & \\
\hline 1 (Constant) & 25.759 & 3.966 & & 6.495 & .000 \\
\hline $\begin{array}{l}\text { Penguasaan } \\
\text { Sintaksis (X1) } \\
\end{array}$ & 1.077 & .298 & .448 & 3.614 & .001 \\
\hline Penalaran (X2) & 1.344 & .327 & .509 & 4.105 & .000 \\
\hline
\end{tabular}

a. Dependent Variabel: Kemampuan Menulis

Paragraf Eksposisi (Y)

Tabel 2 Hasil Uji Regresi Variabel $X_{1}$ dan $X_{2}$ Secara Besama-sama Terhadap Variabel Y

\begin{tabular}{|c|c|c|c|}
\hline \multicolumn{4}{|c|}{ ANOVA $^{b}$} \\
\hline Model & Sum of Squares df & Mean Square & Sig. \\
\hline 1 Regression & $4217.696 \quad 2$ & 2108.848 & $61.520 .000^{\mathrm{a}}$ \\
\hline Residual & 1028.36430 & 34.279 & \\
\hline Total & 5246.06132 & & \\
\hline
\end{tabular}

a. Predictors: (Constant), Penalaran (X2), Penguasaan Sintaksis (X1)

b. Dependent Variabel: Kemampuan Menulis Paragraf Eksposisi (Y) 


\section{Hubungan antara Penguasaan sintaksis (X1) dengan kemampuan menulis eksposisi (Y)}

Berdasarkan deskripsi analisis yang didapatkan bahwa total skor penguasaan sintaksis adalah sebesar 594 dengan rata-rata 18, modus 15, median 18. Dari data yang telah diperoleh peneliti, terlihat bahwa mahasiswa kelas A semester 3 STKIP Kususmanegara Jakarta memiliki skor yang berbeda-beda. Ada yang memperoleh skor tinggi maupun rendah. Perbedaan tersebut menunjukkan bahwa penguasaan sintaksis mahasiswa berbeda satu dengan lainnya.

Hubungan penelitian menunjukkan bahwa semakin tinggi skor penguasaan sintaksis maka semakin tinggi kemampuan menulis paragraf eksposisi. Kontribusi penguasaan sintaksis (X1) kepada kemampuan menulis Eksposisi (Y) ditandai dengan nilai p sebesar $0.001<0.05$. Sehingga dapat ditarik kesimpulan bahwa variabel penguasaan sintaksis memiliki hubungan yang signifikan dengan kemampuan menulis paragraf eksposisi.

\section{Hubungan antara penalaran $\left(X_{2}\right)$ dengan kemampuan menulis eksposisi} (Y)

Berdasarkan deskripsi analisis yang didapatkan bahwa total skor penalaran adalah sebesar 567 dengan rata-rata 17.18, modus 15, median 17 . Dari data yang telah diperoleh peneliti, terlihat bahwa mahasiswa kelas A semester 3 STKIP Kususmanegara Jakarta memiliki skor yang berbeda. Ada yang memperoleh skor tinggi maupun rendah. Perbedaan tersebut menunjukkan bahwa tingkat penalaran mahasiswa berbeda satu dengan lainnya.

Hubungan penelitian menunjukkan bahwa semakin tinggi skor penalaran maka semakin tinggi kemampuan menulis paragraf eksposisi. Kontribusi penguasaan sintaksis $\left(\mathrm{X}_{2}\right)$ kepada kemampuan menulis eksposisi (Y) ditandai dengan nilai p sebesar $0.000<0.05$. Sehingga ditarik kesimpulan bahwa variabel penalaran memiliki hubungan yang signifikan dengan kemampuan menulis paragraf eksposisi.

\section{Hubungan antara penguasaan sintaksis (X1) dan Penalaran $\left(X_{2}\right)$ dengan}

\section{kemampuan menulis eksposisi (Y)}

Dari hasil hitungan analisis koefisien ganda antara variabel penguasaan sintaksi $(\mathrm{X} 1)$, Penalaran $\left(\mathrm{X}_{2}\right)$ dan Kemampuan menulis paragraf eksposisi yaitu nilai p sebesar $0.000<0.05$. Selain itu, berdasarkan uji F

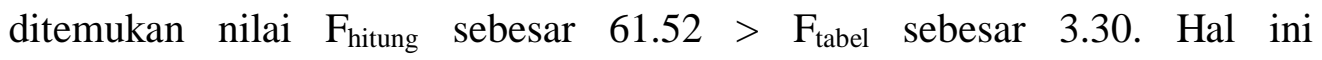
menunjukkan bahwa ketiga variabel tersebut memiliki hubungan yang signifikan secara bersama-sama, maka dapat disimpulkan bahwa semakin tinggi penguasaan sintaksis dan penalaran seseorang maka semakin tinggi pula kemampuan menulis paragraf eksposisi.

Untuk mengetahui besarnya sumbangan dari masing-masing predictor terhadap kriteriumnya, digunakan persamaan sumbangan efektif dan 
sumbangan ralatif. Besarnya sumbangan efektif (SR\%) tiap predictor adalah harga masing-masing koefisien regresi (Beta) dikali koefisien korelasi dikali $100 \%$. Atau, jika dituliskan dengan rumus sebagai berikut:

$\mathrm{SE} \mathrm{X} \%=\mathrm{BetaX} \times \mathrm{r}_{\mathrm{xy}} \times 100 \%$

Keterangan:

$\mathrm{SE}=$ Sumbangan efektif variable $\mathrm{X}$

BetaX = Koefisien regresi

$\mathrm{r}_{\mathrm{xy}}=$ koefisien korelasi

Sedangkan untuk mencari sumbangan efektif (SE\%) masing-masing prediktor terhadap kriterium digunakan rumus sebagai berikut.

$\mathrm{SR} \% \mathrm{X}=\frac{\mathrm{SE} \% \mathrm{X}}{\mathrm{R} 2}$

Keterangan

$\mathrm{SR}=$ Sumbangan efektif variable $\mathrm{X}$

SE X\% = Sumbangan efektif variable $\mathrm{X}$

$\mathrm{R}^{2}=\mathrm{R}$ square

Hasil penelitian menunjukkan bahwa penguasaan kosakata dan tata bahasa Indonesia berpengaruh positif terhadap kemampuan menulis eksposisi. Variabel penguasaan penguasaan sintaksis memberi sumbangan sumbangan efektif sebesar $37.32 \%$ serta sumbangan relatif sebesar $46.42 \%$. Jadi secara keseluruhan, variabel penguasaan sintaksisa dan tata penalaran memberikan sumbangan efektif sebesar $80.4 \%$.

\section{B. Pembahasan}

\section{Kemampuan Menulis Paragraf}

Secara etimologi kata kemampuan berasal dari bahasa Inggris, yaitu competence yang berarti kesanggupan, kecakapan, dan kekuatan. Kata kemampuan diturunkan dari dasar kata mampu dan memperoleh konfiks kean melalui proses afiksasi, yaitu proses atau hasil penambahan afiks pada akar, dasar, atau alas. Sedangkan kata kemampuan berarti pengetahuan tentang bahasa yang bersifat abstrak dan tidak (Kridalaksana, 2013). Kemampuan berarti mampu melakukan sesuatu yang diperoleh melalui pendidikan, menunjukkan performance dan perbuatan yang rasional untuk mencapai tujuan. Selain itu kemampuan menyangkut pula tingkat kesiapan dalam menanggapi, memahami, menghayati dan keterampilan.

Dalam dunia akademisi, kemampuan sangat diperlukan guna menjalankan fungsi mahasiswa sebagai agen perubahan. Di era masyarakat maju dan modern saat ini mahasiswa harus memiliki kemampuan dalam membuat sebuah karya ilmiah yang baik sehingga mahasiswa dituntut untuk dapat menyusun dan menulis paragraf yang baik dan tepat. Menulis berarti 
melahirkan fikiran atau perasaan (seperti mengarang dan membuat surat) dengan tulisan. (Badudu \& Zain, 1994) mengatakan menulis adalah menggunakan pena, potlot, bolpoin di atas kertas, kain atau papan dan sebagainya untuk menghasilkan huruf, kata atau kalimat. Sementara (Tarigan, 2008) memberikan definisi menulis sebagai menurunkan atau melukiskan lambang-lambang grafik yang menggambarkan suatu bahasa yang difahami oleh seseorang, sehingga orang-orang lain dapat membaca lambang-lambang grafik tersebut kalau mereka memahami bahasa dan grafik itu. Dengan demikian peneliti katakan menulis merupakan kegiatan yang menggunakan alat-alat tulis untuk melahirkan gagasan, pikiran atau perasaan dalam bentuk tulisan yang bisa difahami.

Kemampuan menulis bukanlah kemampuan yang diwariskan secara turun temurun, tetapi merupakan hasil proses belajar-mengajar dan ketekunan berlatih (Misra, 2014). Kegiatan menulis jika dikaitkan dengan kemampuan atau keterampilan tidak datang dengan sendirinya, tetapi perwujudan hasil kegiatan belajar dari penguasaan materi dan latihan secara intensif, khususnya dalam penguasaan sintaksis dan penalaran. Dengan kata lain penguasaan sintaksis dan penalaran menjadi komponen yang wajib dikuasai untuk memiliki kemampuan menulis.

Kemampuan menulis juga mempunyai peran yang sangat penting dalam penyampaian pesan kepada orang lain. Hal ini berbanding lurus dengan pernyataan bahwa menulis merupakan kegiatan simbolik yang membuahkan makna; bagaikan kegiatan di ats pentas untuk menyampaikan makna kepada orang lain; cara untuk mengekspresikan diri dan alat untuk berkomunikasi dengan orang lain. Pernyataan ini mempunyai makna bahwa menulis merupakan hasil dari penalaran. Proses penalaran ini akan menghasilkan bahasa yang tersusun dalam susunan-susunan atau struktur kata, baik yang benar maupun yang salah. Kesalahan-kesalahan tersebut terjadi karena adanya hubungan antara tingkatan penguasaan, kemampuan dan performa, ataupun cara penalaran dalam menulis.

Berkaitan dengan kemampuan menulis paragraf, penguasaan sintaksis dan penalaran sangat diperlukan guna menunjang kemampuan dalam membuat suatu tulisan yang sistematis. Gagasan-gagasan dituangkan dalam sebuah tulisan hingga membentuk sebuah paragraf. Paragraf diartikan sebagai bagian bab dalam suatu karangan (biasanya mengandung satu ide pokok dan penulisannya dimulai dengan garis baru); alinea. (Goris Keraf, 2009) merumuskan pengertian Paragraf dengan istilah alinia yaitu satu kesatuan pikiran yang lebih tinggi atau lebih luas dari pada kalimat. Istilah paragraf muncul sekitar tahun 1970-an di Indonesia. Para ahli bahasa umumnya berpendapat sama tentang wacana dalam hal satuan bahasa yang terlengkap (utuh) tetapi dalam hal lain ada perbedaannya. Perbedaannya terletak pada wacana sebagai unsur gramatikal tertinggi yang direalisasikan dalam bentuk 
paragraf yang utuh dengan amanat yang lengkap dan dengan koherensi serta kohesi tinggi. Paragraf yang utuh harus dipertimbangkan dari segi kohesi dan koherensi. "Kohesi adalah keserasian hubungan antara unsur yang satu dengan unsur yang lainnya dalam wacana sehingga terciptalah pengertian yang apik atau koheren, kohesi merujuk pada perpautan bentuk sedangkan koherensi pada perpautan makna". Paragraf adalah rentetan kalimat yang saling berkaitan sehingga terbentuklah makna yang serasi diantara kalimat. Berdasarkan uraian di atas dapat dikatakan bahwa paragraf merupakan satuan bahasa yang terlengkap dan tertinggi di atas kalimat atau klausa dengan kohesi dan koherensi tinggi yang berkesinambungan, yang mempunyai awal dan akhir, yang nyata, yang disampaikan secara lisan atau tertulis.

\section{Hakikat Penalaran}

Penalaran merupakan kegiatan, proses atau aktifitas berpikir untuk menarik suatu kesimpulan atau membuat suatu pernyataan baru berdasarkan pada beberapa pernyataan yang diketahui benar ataupun yang dianggap benar yang disebut premis. (Suriasumantri, 1984) mengartikan penalaran sebagai alur berpikir yang secara sistematis yang dapat diterima akal sehat manusia. Penalaran dalam suatu proses komunikasi bahasa sangat diperlukan karena dari penalaran yang benar didapat makna sesungguhnya yang telah menjadi tujuan dalam kegiatan berkomunikasi. Penalaran adalah kemampuan berpikir menurut suatu alur kerangka berpikir tertentu.

Penalaran bukan hanya sebagai alur berpikir melainkan juga merupakan suatu proses berpikir seorang menuju pada suatu kesimpulan. Hal ini dikemukakan oleh (Arifin, 2012) bahwasanya penalaran adalah suatu proses berpikir manusia untuk menghubung hubungkan data atau fakta yang ada sehingga sampai pada suatu kesimpulan. Berdasarkan pendapat tersebut di atas, data atau fakta yang dinalar itu boleh benar dan boleh tidak benar. Jadi, letak kerja penalaran adalah proses berpikir kepada suatu kesimpulan.

Kemampuan penalaran adalah kinerja seseorang dalam menggunakan nalar atau kinerja dalam berpikir logis. Hakekat kemampuan berpikir logis adalah kemampuan berpikir atau penalaran seseorang baik secara induktif maupun deduktif secara sistematis untuk mendapatkan kesimpulan (Siahaan, 2016).

\section{Pengertian Sintaksis}

Sintaksis merupakan struktur internal bahasa dalam objek kajian ilmu linguistik. Dalam bukunya yang berjudul La Syntaxe du Fransais, Guiraud menjelaskan pengertian sintaksis sebagai studi tentang hubungan kata-kata di dalam wacana. Selain itu dijelaskan juga bahwa sintaksis adalah studi tentang bentuk sintagma atau kombinasi kata-kata. Sedangkan (Verhaar, 2012) menjelaskan kata sintaksis berasal dari bahasa Yunani "sun" yang berarti „dengan" dan "tatein” yang berarti „menempatkan". Jadi secara etimologi 
sintaksis berarti menempatkan bersama-sama kata-kata menjadi kelompok kata atau kalimat.

Sintaksis merupakan tatabahasa yang membahas hubungan antara kata-kata di dalam sebuah tuturan. Tata bahasa sendiri terdiri atas morfologi yang menyangkut struktur gramatikal di dalam kata dan sintaksis yang mempelajari tatabahasa di antara kata-kata di dalam tuturan. Dalam bukunya yang berjudul Asas-Asas Linguistik Umum, (Verhaar, 2012) juga menjelaskan pengertian sintaksis sebagai cabang ilmu linguistik yang menyangkut susunan kata-kata di dalam kalimat. Sintaksis adalah ilmu yang mempelajari hubungan antara kata atau frase atau klausa atau kalimat yang satu dengan kata atau frase (klausa atau kalimat yang lain atau tegasnya mempelajari seluk-beluk frasa, klausa, kalimat dan wacana. Pengertian sintaksis sebagai bagian dari tata bahasa yang menjelaskan aturan-aturan penggabungan unit-unit tanda dalam kalimat; sintaksis, yang mengatur tentang fungsi-fungsisecara umum dibedakan dari morfologi, kajian tentang bentuk-bentuk atau bagian-bagian dari wacana, fleksi dan pembentukan kata atau derivasi). Dari beberapa pengertian sintaksis di atas, dapat disimpulkan bahwa sintaksis adalah ilmu kajian bidang linguistik yang mempelajari tentang tata bahasa di antaranya struktur-struktur frase, klausa, dan kalimat.

Tata bahasa terbagi atas subsistem morfologi dan subsistem sintaksis Kajian dalam morfologi meliputi kata, bagian kata dan kejadian kata.Sintaksis meliputi kata dan satuan yang lebih besar seperti frasa, klausa, kalimat, serta hubungan antara satuan-satuan itu (Kridalaksana, 2013).

\section{Kesimpulan}

Adanya pengaruh yang positif penguasaan sintaksis terhadap kemampuan menulis paragraf eksposisi memberikan petunjuk bagi tenaga pengajar Bahasa dan Sastra Indonesia termasuk di dalamnya mahasiswa akan pentingnya pengajaran sintaksis secara efektif. Hal ini memberikan petunjuk bagi para siswa untuk berusaha menambah pengetahuan tentang sintaksis dengan berbagai cara. Misalnya dengan membaca, agar kemampuan menulisnya lebih baik.

Adanya pengaruh yang positif penalaran terhadap kemampuan menulis paragraf eksposisi memberikan petunjuk bagi tenaga pengajar Bahasa dan Sastra Indonesia, termasuk di dalamnya mahasiswa akan pentingnya pengajaran tentang penalaran yang efektif. Hal ini memberikan petunjuk agar para pengajar Bahasa dan Sastra Indonesia tidak mengabaikan akan pentingnya penalaran agar nantinya karya tulisan mahasiswa lebih baik, lebih sistematis dan lebih mudah dipahami oleh pembacanya. 
Hubungan Penguasaan Sintaksis dan Penalaraan dengan Kemampuan Menulis Paragraf Eksposisi

\section{BIBLIOGRAFI}

Agustin, Y. (2015). Penguasaan Tata Bahasa Dan Berpikir Logik Serta Kemampuan Menulis Artikel Ilmiah. Faktor Jurnal Ilmiah Kependidikan, 2(2).

Arifin, Z. (2012). Evaluasi Pembelajaran. Rosda Karya.

Badudu, Y., \& Zain, S. M. (1994). Kamus umum bahasa Indonesia. Pustaka Sinar Harapan.

Goris Keraf. (2009). Diksi dan Gaya Bahasa. PT Gramedia Pustaka Utama.

Kridalaksana, H. (2013). Kamus Linguistik (edisi keempat). Gramedia Pustaka Utama.

Misra, M. (2014). Peningkatan Kemampuan Menulis Pengumuman Melalui Metode Latihan Siswa Kelas IV SD Inpres 2 Gio Kecamatan Moutong. Jurnal Kreatif Online, 1(2).

Muflikh, T. N. (2016). Penerapan Model Clustering Untuk Meningkatkan Motivasi Belajar Dan Kemampuan Siswa Dalam Menulis Teks Narrative. Syntax Literate; Jurnal Ilmiah Indonesia, 1(2), 66-79.

Nursalam, N., Angriani, A. D., \& Usman, H. (2017). Pengembangan Tes Kemampuan Penalaran Matematis Peserta Didik Madrasah Tsanawiyah Di Makassar. Lentera Pendidikan: Jurnal Ilmu Tarbiyah Dan Keguruan, 20(1), 85-97.

Radford, A. (2004). English syntax: An introduction. Cambridge University Press.

Ridwan, S. (2011). Metodologi pembelajaran bahasa: Aplikasi dalam pengajaran morfologi-sintaksis. Yogyakarta: Kepel Press.

Rimadani, E., Parno, P., \& Diantoro, M. (2017). Identifikasi Kemampuan Penalaran Ilmiah Siswa SMA pada Materi Suhu dan Kalor. Jurnal Pendidikan: Teori, Penelitian, Dan Pengembangan, 2(6), 833-839.

Siahaan, L. H. (2016). Hubungan Antara Kemampuan Berpikir Logis Dan Pengetahuan Tentang Paragraf Dengan Keterampilan Menulis Esai Bahasa Inggris. Sosio Religi: Jurnal Kajian Pendidikan Umum, 14(2).

Suriasumantri, J. S. (1984). Filsafat ilmu: Sebuah pengantar populer. Sinar Harapan.

Tarigan, H. G. (2008). Menyimak Sebagai Suatu Keterampilan Berbahasa. Angkasa Bandung.

Verhaar, J. W. M. (2012). Asas-Asas Linguistik Umum [The Principles of General Linguistics]. Yogyakarta: UGM Press. 